\title{
Educação alimentar e nutricional: estratégia de intervenção com docentes do ensino infantil
}

Camilla Reis Honório, Mariana de Santis Filgueiras, Edilaine Lopes de Freitas, Poliana Cristina de Almeida Fonseca, Silvia Eloiza Priore

\section{Resumo}

Promoção de saúde com crianças requer ações que incluam atividades educativas específicas para faixa etária e nível de compreensão cognitiva. O professor é reconhecido como modelo estimulador na inserção de hábitos saudáveis. Assim dessa forma, esses profissionais devem se conscientizar de sua importância na construção de hábitos alimentares adequados na infância. Capacitar os docentes de ensino infantil por meio da educação alimentar e nutricional, a fim de promover o conhecimento apropriado no ambiente escolar. Trata-se de um estudo de intervenção, cuja amostra foi composta por 8 docentes de uma escola privada que atende crianças com idades de 2 a 6 anos. $\mathrm{O}$ estudo foi desenvolvido em 3 etapas: no primeiro momento avaliou-se o grau de conhecimento dos docentes em relação ao tema alimentação e nutrição, utilizando-se questionário elaborado por Macedo et al. (2008) e dinâmica denominada "Pirâmide em Branco", na qual os professores preencheram uma pirâmide alimentar com os alimentos, que estes julgaram ser saudáveis. Na segunda etapa realizouse capacitação com os professores referente às noções básicas de nutrição e a dinâmica "Troca de Ideias" e foram propostos materiais de apoio didático e atividades como, teatros e visitas à horta em escolas, para estimular os docentes e seus alunos a discutirem temas relacionados à nutrição. $\mathrm{Na}$ etapa final, com objetivo de avaliar o conhecimento adquirido, os professores responderam ao mesmo questionário aplicado na primeira etapa. Logo após, foi realizada uma dinâmica descrita como "A Árvore do Conhecimento", onde cada professor recebeu uma folha, uma flor e um fruto em papel para escrever sua opinião sobre o projeto. Na flor, o que foi bom, mas que poderia ser melhorado; no fruto o que consideravam tão bom ao ponto de não haver necessidade de mudanças; e na folha relataram sugestões sobre a atuação de educação alimentar e nutricional na escola. Ao final, os recortes foram anexados em um tronco de uma árvore colado no quadro e houve uma discussão baseada no ponto de vista de cada um. Na avaliação aplicada antes e após a capacitação, a média geral de conhecimento a intervenção educativa foi de 8,20 e 9,40, respectivamente de um total de 10 pontos possíveis. Após as atividades, notou-se maior conscientização dos docentes quanto ao seu papel no incentivo a bons hábitos alimentares, uma vez que, tradicionalmente, a formação dos educadores brasileiros não contemple essa dimensão. A intervenção aprimorou o conhecimento referente à alimentação e nutrição, além da percepção dos professores a respeito de sua importância em ações educativas que visam construir bons hábitos alimentares desde a infância.

Descritores: Educação alimentar e nutricional; Infância. 